\title{
Erosion, deposition and replacement of soil organic carbon in Mediterranean catchments: a geomorphological, isotopic and land use change approach
}

\author{
E. Nadeu ${ }^{1}$, A. A. Berhe ${ }^{2}$, J. de Vente ${ }^{3,4}$, and C. Boix-Fayos ${ }^{1}$ \\ ${ }^{1}$ Centro de Edafología y Biología Aplicada del Segura (CEBAS-CSIC), Campus Universitario de Espinardo, \\ 30100 Murcia, Spain \\ ${ }^{2}$ School of Natural Sciences, University of California-Merced, 4225 N. Hospital Rd, Castle \# 47, Atwater, CA 65301, USA \\ ${ }^{3}$ Estación Experimental de Zonas Áridas (EEZA-CSIC), Carretera de Sacramento, s/n, 04120, La Cañada de San \\ Urbano-Almería, Spain \\ ${ }^{4}$ Department of Geography and Environment, School of Geosciences, University of Aberdeen, St. Mary's Aberdeen \\ AB243UF, UK
}

Correspondence to: E. Nadeu (enadeu@ cebas.csic.es)

Received: 7 July 2011 - Published in Biogeosciences Discuss.: 18 August 2011

Revised: 2 February 2012 - Accepted: 8 March 2012 - Published: 27 March 2012

\begin{abstract}
Determination of whether soil erosion can constitute a net terrestrial carbon dioxide $\left(\mathrm{CO}_{2}\right)$ sink continues to suffer from lack of sufficient focused studies and field data. Two of the major gaps in our understanding of the erosion induced terrestrial carbon sink issue include rate of eroded soil organic carbon replacement by production of new photosynthate and stability of eroded organic carbon (OC) post deposition. Here we examined the effect of erosion processes and land use change on the stock, type, and stability of OC in two medium-sized subcatchments (18 and 50 ha in size) in SE Spain. We analysed soil samples from drainage areas and depositional settings for stock and isotopic composition of OC $\left({ }^{14} \mathrm{C}\right.$ and $\left.{ }^{13} \mathrm{C}\right)$, and particle size distribution. In addition, we conducted land use change analysis for the period 19562008 and a geomorphological survey of the current erosion processes taking place in the slope-streambed connections. Our findings demonstrate that land use change influenced the dominating erosion processes and, thus, the source of eroding sediments. Carbon isotopes used as tracers revealed that in one of the subcatchments the deposited sediments were derived from deep soil (average $\Delta^{14} \mathrm{C}$ of $-271.5 \%$ ) through non-selective erosion processes and channel incision. In the other subcatchment, topsoil material was predominantly eroded and the average $\Delta^{14} \mathrm{C}$ in sediments was $-64.2 \%$. Replacement of eroded soil OC was taking place in the analysed soil profiles in the slopes suggesting that erosion processes do not necessarily provoke a decrease in soil OC stock over time.
\end{abstract}

\section{Introduction}

Soil erosion is a ubiquitous process that redistributes topsoil and associated soil OC within and out of watersheds. Over the last 15 years, it has become clear that improved understanding of how soil OC is detached, transported and deposited over the landscape, and the factors that can cause this to change, is essential to close the global carbon budget (Berhe et al., 2007; Stallard, 1998). Moreover, there is a critical need to get better understanding of the stability and stabilization mechanisms of eroded OC in depositional sites and to what extent $\mathrm{OC}$ lost from eroded slopes can be replaced by new OC input from vegetation (Berhe et al., 2008, 2012, and Van Oost et al., 2007).

Proper identification and accounting of the source and fate of eroded soil OC arriving at different types of depositional environments remain among the most significant gaps in our ability to accurately quantify the contribution of soil erosion to terrestrial $\mathrm{CO}_{2}$ sequestration (Berhe et al., 2007, 2012; Harden et al., 1999; Van Hemelryck et al., 2010). Identification of sediment sources (from different parts of a catchment) and factors that control source variability are critical since the concentration and composition of $\mathrm{OC}$ in the mobilized sediment, the rate of OC enrichment in sediments (Collins et al., 1997) and the fate of the mobilized OC depend on the characteristics of the source material-which can include soil, plant debris, litter, and bedrock. Lithology and geomorphic variables, such as slope gradient and length, exert a primary control on the type of erosional processes and the rate of 
sediment redistribution (Romero-Diaz et al., 2007). Land use changes and changes in precipitation regimes also strongly influence the nature and rate of erosion through their effect on hydrological and sedimentary dynamics at the catchment scale (Boix-Fayos et al., 2007) and, consequently, the concentration and composition of OC in the exported sediments can vary depending on the nature of the prevailing erosional processes (Nadeu et al., 2011). Additionally, shifts in water flowpaths over time can also lead to changes in amount and composition of eroded OC (Gómez et al., 2010; Hilton et al., 2008; Raymond and Bauer, 2001; Schiff et al., 1997) with implications for greenhouse gas emissions in source soils and depositional settings.

Determination of the fate (post-detachment decomposition kinetics) of the eroded OC during transport and deposition (Berhe, 2012) and its rate of replacement in the soils of eroded landform positions (Berhe et al., 2008) are key for improved understanding of the role of erosion in carbon sequestration. The criterion for soil erosion to constitute a net carbon sink states that dynamic replacement of eroded carbon in eroding sites, and protection from decomposition upon burial at depositional sites must together more than compensate for erosional losses of soil OC from the catchment (Berhe et al., 2007). Thus, only if at least some of the eroded OC is preserved in depositional sites, and/or replaced by new photosynthate at eroding slopes can soil erosion constitute a net $\mathrm{CO}_{2}$ sink (Berhe et al., 2008; Stallard, 1998). Therefore, in order to assess the effect of different factors on OC sequestration and replacement, catchment scale studies are needed to complement and verify laboratory based results, which, in some cases, mismatch field observations (Van Hemelryck et al., 2011).

Carbon isotopes $\left({ }^{13} \mathrm{C}\right.$ and $\left.{ }^{14} \mathrm{C}\right)$ are of special interest for catchment scale assessments of $\mathrm{OC}$ erosion, deposition and replacement. On the one hand because both, ${ }^{13} \mathrm{C}$ and ${ }^{14} \mathrm{C}$, can be used as tracers of sources of sediment; ${ }^{13} \mathrm{C}$ has been used to trace soil erosion processes in a qualitative way (Alewell et al., 2008) and its applications and those of the radioisotope ${ }^{14} \mathrm{C}$ are increasing: (i) establish $\mathrm{OC}$ sources and flowpaths in riverine sediments (Alin et al., 2008; Gomez et al., 2010; Hilton et al., 2008; Lambert et al., 2011; Masiello and Druffel, 2001; Schiff et al., 1997) and, from them, qualitatively assess the intensity of erosion processes (Wei et al., 2010); (ii) discriminate between autochthonous and allochthonous OM in rivers and estuaries (McCallister et al., 2004) (iii) reconstruct sediment transport and deposition rates in basins (Kitagawa et al., 2010; Saint-Laurent et al., 2010) and (iv) trace land use changes and their effect on SOC (Harrison et al., 1993; Katsuno et al., 2010). On the other hand, the radioactive isotope can also be used to trace carbon cycling (Gaudinski et al. 2000; Marzaioli et al., 2010; Masiello and Druffel, 2001) and determine OC turnover rates and input to soil. This last application can be used to estimate OC replacement rates on eroded slopes when coupled with erosion rates (Berhe et al., 2008). Therefore, ${ }^{14} \mathrm{C}$ is a valuable tool to assess different aspects of OC dynamics as it can provide information on OC input to soil and be used to trace sources of sediment at the same time.

In this study we used a combined approach based on a carbon isotope study $\left({ }^{13} \mathrm{C}\right.$ and $\left.{ }^{14} \mathrm{C}\right)$, geomorphological surveys and land use change analysis. We aimed to (i) identify sources and fate of OC affected by soil erosion processes in two Mediterranean catchments and (ii) analyse the implications of $\mathrm{OC}$ redistribution on $\mathrm{CO}_{2}$ sequestration at two landscape positions (eroding and depositional sites).

\section{Study site and methods}

\subsection{Study site}

The study was carried out in two subcatchments of the Rogativa catchment $\left(\sim 50 \mathrm{~km}^{2}\right)$ located in Murcia (SE Spain) (Fig. 1). The region is characterized by a Mediterranean climate with a mean annual temperature and precipitation of $13.3^{\circ} \mathrm{C}$ and $583 \mathrm{~mm}$, respectively. The area has undergone considerable land use changes in the last thirty years, through decreasing proportion of land area used for rainfed agriculture and increasing proportion of area covered by secondary forests as a result of both natural succession and reforestation. Vegetation is currently dominated by forest cover (P. nigra-salzmanii, $P$. halepensis, $P$. pinaster) (Boix-Fayos et al., 2007). Two contrasting subcatchments with the same pluviometric conditions, at a distance of $6 \mathrm{~km}$ from each other, were selected for this study: Subcatchment C51 (50 ha), ravine of "La Suerte Estrecha" $\left(38^{\circ} 8^{\prime} 11^{\prime \prime} \mathrm{N}, 2^{\circ} 13^{\prime} 42^{\prime \prime} \mathrm{W},\right)$ and subcatchment $\mathrm{C} 24$ (18 ha), ravine of 'Loma Parrilla' $\left(38^{\circ} 6^{\prime} 3^{\prime \prime} \mathrm{N}, 2^{\circ} 14^{\prime} 15^{\prime \prime} \mathrm{W}\right)$. In general terms, C51 has a larger drainage area, while average slope of the drainage area and the stream are similar for both subcatchments (Table 1). Lithology at both sites is characterized by a mixture of marls, limestones and sandstones from the Cretaceous (IGME 1978) in addition to an outcrop of quaternary glacis in C24 (Table 1). The two subcatchments differ with regards to the nature of erosion processes. Water flows through the streams very seldom throughout the year with a strong dependence on the occurrence of precipitation events. The subcatchments are delimited by a checkdam at their outlet that was built following hydrological correction works that were promoted by the government during the 1970's. These check-dams, built in 1977, have a trapping efficiency of $71 \%$ and $87 \%$, for $\mathrm{C} 51$ and $\mathrm{C} 24$ respectively (Boix-Fayos et al., 2008). C51 and C24 were chosen for this study because they represented contrasting history of land use changes and, therefore, allow examination of the effect of different land use histories on OC dynamics. C24 represented a relatively stable land use situation of semicontinuous forest cover during the whole period of observation, from 1956 to 2008. In contrast, C51 experienced reduction in agricultural land over the last 40 years (Boix-Fayos 


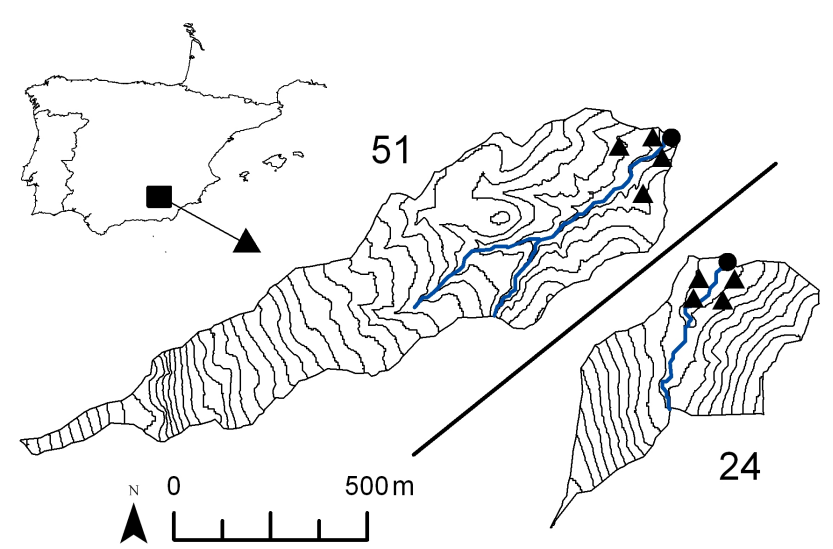

Fig. 1. General location and details of the two subcatchments (C51 and C24), the check-dam (black circle) and of the soil pits (black triangles).

et al., 2008). Soil OC erosion rates for the sampled locations were calculated from mean annual erosion rates derived from the estimation of the volume of sediments deposited behind the check-dams (Table 1) and the application of the WATEM/SEDEM model in a previous study (Boix-Fayos et al., 2008).

\subsection{Sampling of soils and sediments}

To trace the erosion process and determine mean residence time of OC, two landform positions were selected: eroding slopes and depositional sites. The sediment wedge retained behind the check-dam present at the outlet of each catchment was defined as the depositional site at the subcatchment scale and was covered with annual grasses and sparsely distributed shrubs at the time of sampling. In each subcatchment, four soil profiles and two sediment profiles were sampled (see Fig. 1). Soil pits were dug on slopes (20-30\% steepness) that had a stable land-use history since 1950 and that kept a maximum distance of $50 \mathrm{~m}$ to the depositional site. The last premise assured that the selected profiles were well connected to the depositional site and were a potential source of sediments during the studied period. All soil pits were located under pine forest cover, representative for more than $80 \%$ of the area in each subcatchment, except one located under shrub in C51. From each soil profile, samples were taken in $5 \mathrm{~cm}$ increments for the topsoil $(0-5,5-10)$, then every $10 \mathrm{~cm}(10-20,20-30)$ and finally every $15 \mathrm{~cm}$ down to $90 \mathrm{~cm}$ or until the saprolite boundary was reached. In total 32 in-depth soil samples were collected in each subcatchment in spring 2010 ( 8 for each profile). Bulk density cores $\left(100 \mathrm{~cm}^{3}\right)$ were taken for each sampled depth. Sediment samples were taken in Summer 2009 in bare patches within the sediment wedge in $5 \mathrm{~cm}$ increments until bedrock was reached in two locations (Fig. 2): behind the check-dam (A profile) (down to 70 and $80 \mathrm{~cm}$ depth for C51 and C24, respectively) and at the end of the sediment wedge (B profile) (reaching $50 \mathrm{~cm}$ depth in C51 and $20 \mathrm{~cm}$ depth in C24). A replicate was taken for both locations (A and B in each subcatchment) in $15 \mathrm{~cm}$ increments.

\subsection{Geomorphological mapping and land use change}

A geomorphological survey based on the methodology proposed by Hooke (2003) was conducted in each subcatchment to identify dominant erosion processes and current sediment source areas along the slope-streambed connections. The whole stream was characterized in C24 (430 m aprox.), while only two thirds of it were mapped in C51 (500 m aprox.). Processes were classified as: interrill erosion, rill erosion, gullies, creeping, mass waste and bank erosion. Further, the streambed was surveyed to detect aggradation and degradation features in the channel such as depositional bars, rock outcrops, incision, slope breakdowns and pools.

Land use data was derived from manual digitalization of three orthophotos from 1956 (American flight, spatial resolution $1 \mathrm{~m}$ ), 1981 (General Directorate of Landscape Planning, Region of Murcia, spatial resolution $1 \mathrm{~m}$ ) and 2008 (Natmur08 Project of the General Directorate of Natural Heritage and Biodiversity, Region of Murcia, spatial resolution $0.45 \mathrm{~m}$ ). Land use units were digitalized and coded using GRASS software and classified into one of these five categories: high density forest (HDF), low density forest (LDF), reforested areas (REF), shrubland (SH) and dry-land agriculture (DLA) (Boix-Fayos et al., 2007). Geology and lithology were derived from the digital geological maps of the IGME (1978) at 1:50000 in combination with own field observations.

\subsection{Particle size distribution and OC}

All soil and sediment samples were oven-dried at $60^{\circ} \mathrm{C}$, gently crushed and passed through a $2 \mathrm{~mm}$ sieve. Samples for texture analysis were treated with $\mathrm{H}_{2} \mathrm{O}_{2}$ to oxidate organic matter and were later chemically dispersed by a mixture of sodium hexametaphosphate and sodium carbonate anhydrous for 18-24h. After this, particle size distribution was determined using a combination of wet sieving ( $>63 \mu \mathrm{m}$ particles), for the sand fraction, and laser diffractometry techniques $(<63 \mu \mathrm{m})$ for the silt and clay fractions in a Coulter LS200 (Miami, USA). Samples for analysis of total carbon and $\mathrm{N}$ were ground using a 8000M SPEX mill before they were analysed by the dry combustion technique using a Costech ECS 4010 at UC Merced (Berhe et al., 2008). $\mathrm{C}: \mathrm{N}$ ratios were calculated based on the $\% \mathrm{OC}$ and $\% \mathrm{~N}$ in each sample. Particulate organic carbon (POC; $>53 \mu \mathrm{m}$ ) was separated from mineral-associated organic carbon (MOC; $<53 \mu \mathrm{m}$ ) by wet sieving after dispersion with sodium hexametaphosphate and organic carbon was determined through the wet oxidation method (Yeomans and Bremner, 1988). Enrichment ratios in sediment samples for a given parameter were calculated as the ratio between the value measured 
Table 1. Morphological and land use change characteristics of study subcatchments C24 and C51 (positive land use change values indicate increase in 2008 and viceversa). SLN: average slope of the drainage network, SY: sediment yield, HDF: high density forest, LDF: low density forest, SH: shrubland, DLA: dry-land agriculture, *average values reported.

\begin{tabular}{llllllllll}
\hline & \multicolumn{4}{c}{ Morphological variables } & \multicolumn{3}{c}{ Land use change 1956-2008 } \\
\cline { 2 - 9 } Id & $\begin{array}{l}\text { Area } \\
(\mathrm{ha})\end{array}$ & $\begin{array}{l}\text { Slope* }^{*} \\
\left({ }^{\circ}\right)\end{array}$ & $\begin{array}{l}\text { Elevation* } \\
(\mathrm{m})\end{array}$ & $\begin{array}{l}\text { SLN } \\
\left({ }^{\circ}\right)\end{array}$ & $\begin{array}{l}\text { SY } \\
\left(\mathrm{tn} \mathrm{yr}^{-1}\right)\end{array}$ & $\begin{array}{l}\text { HDF } \\
(\%)\end{array}$ & $\begin{array}{l}\text { LDF } \\
(\%)\end{array}$ & $\begin{array}{l}\text { SH } \\
(\%)\end{array}$ & $\begin{array}{l}\text { DLA } \\
(\%)\end{array}$ \\
\hline C51 & 50 & 16.4 & 1213.2 & 11.5 & 45.7 & 1.4 & 25.6 & -1.4 & -25.6 \\
C24 & 18 & 17.8 & 1274.7 & 10.4 & 34.4 & 2.2 & -2.8 & 8.4 & -7.8 \\
\hline
\end{tabular}

\section{C51}
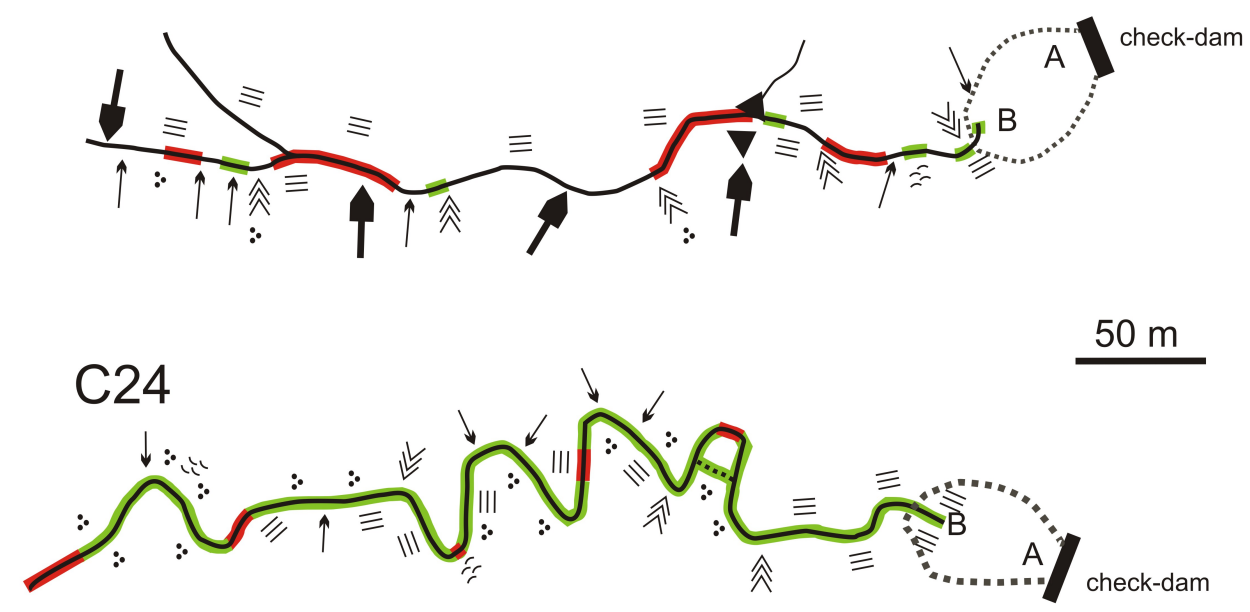

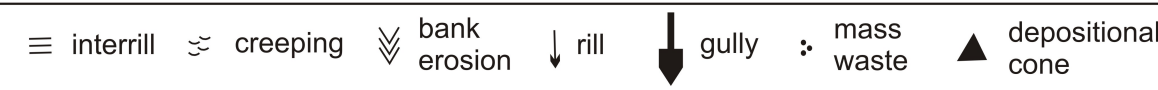

$$
\begin{aligned}
& \text { aggradation bed erosion _.... sediment wedge A,B depositional profiles }
\end{aligned}
$$

Fig. 2. Schematic geomorphological representation of the two streams indicating the main erosion and depositional processes.

in sediments to the average parameter value computed from soils sampled in the drainage area (reference values from 0 $10 \mathrm{~cm}$ topsoil).

\section{$2.5{ }^{13} \mathrm{C}$ and ${ }^{14} \mathrm{C}$ analysis}

One sediment profile and one soil profile under forest cover in both subcatchments were selected for ${ }^{14} \mathrm{C}$ analysis on bulk soil OC. Visible roots were removed from the samples to ensure sample homogeneity. This was done during a fixed period of time by one single person. After root removal, samples were ground to fine powder using a 8000M SPEX mill and washed with $1 \mathrm{~N} \mathrm{HCl}$ to eliminate carbonates. The carbonate free samples were processed at the KCCAMS lab at UC Irvine. ${ }^{13} \mathrm{C}$ was measured on $\mathrm{CO}_{2}$ using a gas bench coupled with isotope ratio mass spectrometer (IRMS) (Finnigan Delta Plus) while the $\Delta^{14} \mathrm{C}$ was determined by accelerator mass spectrometry (AMS) on graphite, following the methods of Xu et al. (2007) and Southon and Santos (2007). The obtained data were corrected for isotopic fractionation according to the conventions of Stuiver and Polach (1977). The $\Delta^{14} \mathrm{C}$ and $\delta^{13} \mathrm{C}$ values reported here are the \%o deviation of a standard corrected to a $\delta^{13} \mathrm{C}$ of $-25 \%$ and they represent a mean of the OC pools present in each bulk soil and sediment sample. $\delta^{13} \mathrm{C}$ and $\Delta^{14} \mathrm{C}$ values are reported with an analytical uncertainty of $0.15 \%$ and $1.5-2 \%$ respectively. 


\subsection{Profile-integrated $\mathrm{OC}$ input and $\mathrm{OC}$ decomposition rate}

To obtain soil OC input $\left(\mathrm{C}_{\mathrm{in}}\right)$-the fraction of net primary productivity that, after rapid initial decomposition, remains as actual input of carbon to the soil OC pool- the rate of OC accumulation in the soil profiles was reconstructed according to a first order model of OC accumulation (Trumbore and Harden, 1997). This model assumes that OC in soil accumulates preferentially from top to bottom, where the inventory of $\mathrm{OC}$ is calculated as:

$\mathrm{OC}_{\mathrm{inv}}=\sum \Delta Z_{i} \times \rho_{i} \times\left(1-R_{i}\right) \times\left(\frac{\% \mathrm{OC}_{i}}{100}\right)$

Where $\mathrm{OC}_{\mathrm{inv}}$ is the $\mathrm{OC}$ inventory for the whole profile $\left(\mathrm{g} \mathrm{m}^{-2}\right), \Delta Z_{i}$ the depth of layer " $i$ " (m), $\rho_{i}$ bulk density of the " $i$ " layer $\left(\mathrm{g} \mathrm{m}^{-3}\right), R_{i}$ the rock fraction and \%OC the OC content in the " $i$ " layer. The $\mathrm{OC}_{\text {inv }}$ on a certain moment in time $\mathrm{OC}_{\mathrm{inv}}(t)$ is expressed as:

$\mathrm{OC}_{\mathrm{inv}}(t)=\frac{\mathrm{C}_{\mathrm{in}}}{k}\left[1-\mathrm{e}^{-k t}\right]$

Where $\mathrm{C}_{\text {in }}$ is the input rate of $\mathrm{OC}$ into the soil matrix $\left(\mathrm{g} \mathrm{m}^{-2} \mathrm{yr}^{-1}\right)$ and $k$ is an average coefficient of first-order carbon loss for all soil layers $\left(\mathrm{yr}^{-1}\right)$ that can be further splitted into two components: loss by oxidation $\left(k_{d}\right)$ and loss by erosion $\left(k_{\mathrm{e}}\right)$, when $\mathrm{OC}$ erosion rates are known. The $\mathrm{OC}_{\text {inv }}$ was plotted in a graph against the mean ${ }^{14} \mathrm{C}$ age in each soil layer, calibrated to calendar years using OxCal (OxCal-IntCal09 from Oxford University, Bronk Ramsey, 2009). The plotted data were fitted in Eq. (2) and solved using a least squares approach with the solver function in Excel (MS Office 2003) to obtain the $\mathrm{C}_{\text {in }}$ and $k$ parameters, assuming that the ${ }^{14} \mathrm{C}$ signature of the $\mathrm{OC}$ input remained constant over the years. The $\mathrm{C}_{\mathrm{in}}$, thus, represents a mean carbon input throughout the whole period of formation of the soil profile and it can be combined with an erosion rate to obtain an estimate of OC replacement (Berhe et al., 2008).

In addition, the storage effectiveness of the eroding vs. depositional positions for $\mathrm{OC}$ in the soil and sediment profiles, respectively, was determined according to methods of Masiello et al. (2004) and Berhe et al. (2008):

$\mathrm{FM}_{w}=\frac{1}{\mathrm{OC}_{\mathrm{inv}, \mathrm{tt}}} \cdot \sum \mathrm{FM}_{i} \cdot \mathrm{OC}_{\mathrm{inv}, \mathrm{i}}$

Where FM is the fraction modern of $\mathrm{OC}, \mathrm{FM}_{w}$ is the mean value of the $\mathrm{FM}$ weighted with the $\mathrm{OC}$ content; $\mathrm{OC}_{\mathrm{inv}, \mathrm{tt}}$ the total $\mathrm{OC}$ inventory, $\mathrm{FM}_{i}$ the fraction modern of $\mathrm{OC}$ in the " $i$ " depth and $\mathrm{OC}_{\mathrm{inv}, i}$ the $\mathrm{OC}$ inventory in the " $i$ " depth. The $\mathrm{FM}_{w}$ value is comprised between 0 and 1 , where 0 represents the maximum OC storage effectiveness (storage of old OC) and 1 represents the opposite, least OC storage effectiveness.

\section{Results}

\subsection{Land use changes, erosion processes and sediment sources}

The two study subcatchments had different land use history, but both experienced a greening-up and densification of vegetation cover since 1956 (Table 1). About 14 ha ( $28 \%$ of the total area) of dry-land agriculture of C51 present in 1956 were reforested in 1981. By 2008, the vegetation in the reforestation terraces had grown and was classified as a low density forest. In contrast, C24 remained mostly under a continuous cover of forest and shrubland, and the small patches of agricultural land present in 1956 were converted to high density forest cover by 2008 (Table 1). These changes observed in both subcatchments are in agreement with the general pattern of afforestation and agriculture abandonment described in the region (Boix-Fayos et al., 2008).

The geomorphological survey indicated that gully erosion and bank and river erosion were the main erosion processes supplying sediments to the stream channel in C51. The channel presented signs of degradation (an average incision of $60 \mathrm{~cm}$ and an armour layer) in several reaches. Interrill erosion was identified on south facing slopes of the channel but those slopes appeared often disconnected to the channel due to a continuous shrub cover at the bottom of the slopes which acted as sediment trap (Fig. 3). C24 was characterized by the dominant presence of non-point sources of sediment. The lateral slopes of the channel were well connected to the streambed through interrill erosion processes and the entrance of debris from the colluvial/glacis slopes. The channel showed aggradation in many reaches (Fig. 3).

\subsection{OC concentration, OC fractions and particle size distribution}

OC stocks were higher in the soils of $\mathrm{C} 24$ than in those of C51 $(p<0.001)$ but no differences were found in soil particle size distribution between them. The data also indicated high spatial variability in the measured variables in the soil profiles at similar depths in each subcatchment (Table 2). All soil and sediment samples had silt to loam particle size distribution, with no significant differences between them. OC concentration in soils was negatively correlated to clay content at both sites (for C51 $r=-0.99, p<0.001$ and for $\mathrm{C} 24 r=-0.89 p<0.005)$ and decreased with depth in both $\mathrm{C} 51$ and $\mathrm{C} 24$ (from $2.8 \%$ and $3.8 \%$ in the topsoil to $0.9 \%$ and $1.6 \%$ in the deepest soil layer in C51 and C24, respectively). POC represented $37.9 \pm 11.9 \%$ of total OC measured in the soils of both subcatchments and decreased with depth as well. When soil and sediment samples were compared, significant differences $(p<0.01)$ among the measured parameters were found in C51 for the sand and silt content, the first one being higher in soils and the second one higher in sediments. In C24, significant differences $(p<0.001)$ 

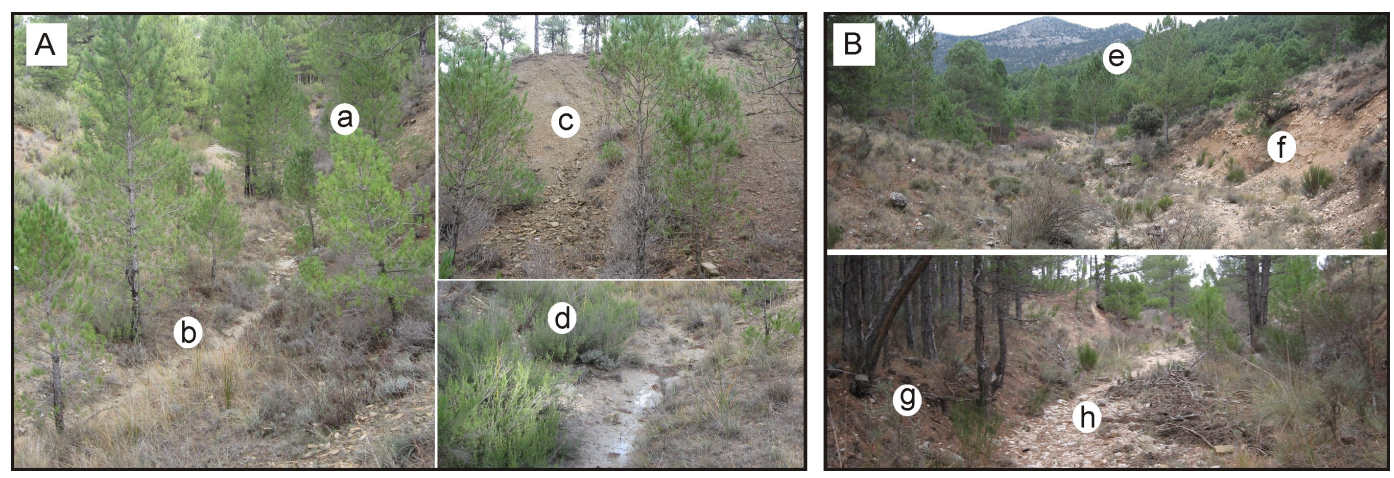

Fig. 3. A (C51): (a) low density forest; (b) vegetation encroachment and channel incision; (c) talus slope with input of sediments by mass waste processes and (d) vegetation in the inner plain and at the slope base retaining eroded material. B (C24): (e) high density forest; (f) talus slopes with a concave base; (g) well-connected lateral slopes with interrill erosion and litter input to the channel and (h) channel aggradation.

concerned: higher $\mathrm{OC}, \mathrm{POC}$ and $\mathrm{MOC}$ concentration and sand content in soils, and higher silt content in sediment.

We observed important differences in particle size distribution in the profiles at the depositional landform positions. Silt was the dominant particle size fraction in the sediment samples collected behind the check-dams (A profiles) being sand content very low $(<20 \%)$, especially in C51 sediments. The sediment wedge was not homogeneous in particle size distribution in C51 as significant differences in sand, silt and clay content were found between the $\mathrm{A}$ and $\mathrm{B}$ profiles $(p<0.001)$. In the opposite, no significant differences were observed between A and B profiles in C24 for particle size distribution. POC contributed to $34 \%$ of total OC in C51 sediments and its contribution was significantly higher (50\%) in C24 (Table 3). In the sediment profiles of C51 (A and B) OC concentration was positively correlated to silt and clay content $(\rho=0.510$ and $\rho=0.547, p<0.05)$ while in C24 only MOC was correlated to silt content ( $\rho=0.714$, $p<0.01$ ).

Carbon concentration was highly reduced in the sediment profiles in comparison with the soil profiles as evidenced by the low enrichment ratios $(<0.5)$ (Table 4$)$. The reduction in OC concentration was greater in C24 than in C51, especially for the A sediment profile. Reduction in MOC concentration was lower than POC concentration. In both, C51 and in C24, sediments were enriched $(E R>1)$ in silt and had clay content similar than that of the soils sampled in the drainage area. In C51, the sediments just behind the dam (profile A) had an $\mathrm{ER}<1$ for sand content and an ER $>1$ for silt and clay content, while those remaining in the back part of the sediment wedge had an ER $>1$ for sand content. In C24, no significant $(p<0.05)$ differences could be found in the particle size ER between A and B sediment profiles.

\subsection{Isotopic composition of soils and sediments and C:N ratio}

The radiocarbon composition of the soil profiles in C51 and C24 indicated that near surface OC was modern (post 1963, photosynthate produced after the atmospheric thermonuclear bomb tests, positive or near zero $\Delta^{14} \mathrm{C}$ values) and $\Delta^{14} \mathrm{C}$ got progressively more negative, possessing longer mean residence times with depth (Fig. 4). The $\Delta^{14} \mathrm{C}$ analyses conducted on bulk soil samples reflect an average radiocarbon concentration in all OC pools and do not enable determination of loss or enrichment of $\mathrm{OC}$ from specific fractions. More negative $\Delta^{14} \mathrm{C}$ values were found in the deeper layers of the C51 soil profile than in the soil profile at C24. Sediment profiles sampled just behind the check-dams (A profiles) showed very different $\Delta^{14} \mathrm{C}$ values between both subcatchments. The A profile in $\mathrm{C} 51$ contained OC associated to a very negative $\Delta^{14} \mathrm{C}$ on the surface that gradually became less negative (from $-400 \%$ o to $-170 \%$ ) with depth. In C24 the $\Delta^{14} \mathrm{C}$ values of the A profile varied with depth and ranged between $-150 \%$ and $0 \%$ showing no specific trend.

The $\delta^{13} \mathrm{C}$ signature of the soil samples became less negative with depth in both C51 and C24, ranging from $-26.1 \%$ o to -23.7 (Table 2). The enrichment of $\delta^{13} \mathrm{C}$ with depth has been related to: (1) the fractionation during decomposition of organic matter and, thus, stabilization of OC fractions that are on average harder to decompose than bulk OC, and (2) to the ${ }^{13} \mathrm{C}$ reduction in the atmosphere and plants due to fossil fuel emissions (Torn et al., 2002), the Suess effect. $\delta^{13} \mathrm{C}$ values in sediments showed very little variation with depth and, overall, the mean $\left( \pm\right.$ std. deviation) $\delta^{13} \mathrm{C}$ value in soils $(-24.8 \pm 0.2 \%$ ) was not significantly different than that in sediments $\left(-24.7 \pm 0.1 \%\right.$ ) . Sediment $\Delta^{14} \mathrm{C}, \delta^{13} \mathrm{C}$ and $\mathrm{OC}$ concentrations were within a range of soil values below $30 \mathrm{~cm}$ in $\mathrm{C} 51$ (Figs. 4, 5) but in $\mathrm{C} 24, \Delta{ }^{14} \mathrm{C}$ and $\delta^{13} \mathrm{C}$ values of sediment samples corresponded, in all cases, to values found in the top $30 \mathrm{~cm}$ of $\mathrm{C} 24$ soil samples (Fig. 4). Also 
Table 2. Bulk density (BD), clay content, OC concentration, C:N ratio, POC $\%$ (percentage of OC $>53 \mu \mathrm{m}$ ), $\delta^{13} \mathrm{C}, \Delta^{14} \mathrm{C}$ and calibrated age (yr B.P.) in soil samples (standard error in brackets).

\begin{tabular}{|c|c|c|c|c|c|c|c|c|c|}
\hline & $\begin{array}{l}\text { Depth } \\
\text { (cm) }\end{array}$ & $\begin{array}{l}\text { Clay } \\
(\%)\end{array}$ & $\begin{array}{l}\mathrm{OC} \\
(\%)\end{array}$ & $\begin{array}{l}\text { OC stock } \\
\left(\mathrm{g} \mathrm{m}^{-2}\right)\end{array}$ & $\begin{array}{l}\mathrm{C}: \mathrm{N} \\
\text { ratio }\end{array}$ & $\begin{array}{l}\text { POC } \%^{\mathrm{a}} \\
(\%)\end{array}$ & $\begin{array}{l}\delta^{13} \mathrm{C}^{\mathrm{b}} \\
(\% \circ)\end{array}$ & $\begin{array}{l}\Delta^{14} C^{b} \\
(\% o)\end{array}$ & $\begin{array}{l}\text { Calibrated age } \\
\text { (yr B.P.) }\end{array}$ \\
\hline \multirow[t]{6}{*}{$\mathrm{C} 51$} & $0-5$ & $11(1)$ & $2.8(0.9)$ & $1704(328)$ & $17(2)$ & $48(6)$ & -26.1 & 78.0 & 27 \\
\hline & $5-10$ & $12(2)$ & $1.9(0.6)$ & 985 (111) & $15(2)$ & $40(8)$ & -25.2 & 59.9 & 110 \\
\hline & $20-30$ & $13(2)$ & $1.4(0.4)$ & $1857(242)$ & $15(2)$ & $33(6)$ & -25.0 & -60.9 & 564 \\
\hline & $30-45$ & $13(2)$ & $1.4(0.4)$ & $3180(813)$ & $15(2)$ & $29(8)$ & -24.8 & -103.9 & 791 \\
\hline & $45-60$ & $12(2)$ & $0.9(0.2)$ & $1902(225)$ & $14(2)$ & $29(9)$ & -24.2 & -203.2 & 1730 \\
\hline & mean & $12(8)$ & $1.5(1.4)$ & $16298^{\circ}(3705)$ & $15(6)$ & $33(20)$ & $-24.8(0.8)$ & $-126.2(61.8)$ & $1522(636)$ \\
\hline \multirow[t]{4}{*}{$\mathrm{C} 24$} & $0-5$ & $11(1)$ & $3.8(0.7)$ & $2406(114)$ & $21(2)$ & $54(4)$ & -25.4 & -4.0 & 57 \\
\hline & $5-10$ & $10(1)$ & $3.2(0.4)$ & $2137(172)$ & $21(2)$ & $47(4)$ & -25.3 & -6.0 & 57 \\
\hline & $10-20$ & $12(1)$ & $2.5(0.4)$ & 3419 (579) & $20(2)$ & 49 (2) & -24.9 & -59.0 & 555 \\
\hline & $20-30$ & $12(1)$ & $2.0(0.2)$ & $2754(416)$ & $20(1)$ & $40(6)$ & -24.2 & -124.6 & 998 \\
\hline
\end{tabular}

${ }^{a}$ Average from 2 soil profiles, ${ }^{b}$ Data from 1 soil profile, standard deviation reported, ${ }^{\mathrm{c}}$ Total value for the profile.

Table 3. Bulk density (BD), clay content, OC concentration, C:N ratio, POC $\%$ (percentage of OC $>53 \mu \mathrm{m}$ ) and $\delta^{13} \mathrm{C}$ in the A profile of the sediment samples (standard error for the whole profile reported).

\begin{tabular}{|c|c|c|c|c|c|c|c|c|c|}
\hline & $\begin{array}{l}\text { Depth } \\
(\mathrm{cm})\end{array}$ & $\begin{array}{l}\text { Sand } \\
(\%)\end{array}$ & $\begin{array}{l}\text { Silt } \\
(\%)\end{array}$ & $\begin{array}{l}\text { Clay } \\
(\%)\end{array}$ & $\begin{array}{l}\mathrm{OC} \\
(\%)\end{array}$ & $\begin{array}{l}\text { OC stock } \\
\left(\mathrm{g} \mathrm{m}^{-2}\right)\end{array}$ & $\begin{array}{l}\text { POC } \% \\
(\%)\end{array}$ & $\begin{array}{l}\delta^{13} \mathrm{C} \\
(\%)\end{array}$ & $\begin{array}{l}\mathrm{C}: \mathrm{N} \\
\text { ratio }\end{array}$ \\
\hline \multirow[t]{12}{*}{ C51 } & $0-5$ & 1 & 86 & 13 & 1.1 & 716 & 15 & -24.0 & 18.6 \\
\hline & $5-10$ & 0 & 84 & 16 & 0.8 & 546 & 19 & -24.2 & 15.7 \\
\hline & $10-15$ & 4 & 83 & 13 & 1.3 & 520 & 27 & -24.2 & 19.3 \\
\hline & $15-20$ & 6 & 81 & 13 & 1.2 & 1113 & 39 & -24.5 & 19.5 \\
\hline & $20-25$ & 4 & 82 & 14 & 1.1 & 800 & 33 & -24.4 & 19.2 \\
\hline & $25-30$ & 5 & 81 & 14 & 1.1 & 1056 & 36 & -24.6 & 17.9 \\
\hline & $30-40$ & 12 & 75 & 13 & 1.4 & 2315 & 53 & -24.9 & 22.1 \\
\hline & $40-50$ & 6 & 81 & 13 & 1.1 & 1589 & 38 & -24.2 & 21.6 \\
\hline & $50-55$ & 7 & 81 & 12 & 1.0 & 1332 & 37 & -24.2 & 20.3 \\
\hline & $55-60$ & 7 & 80 & 13 & 1.2 & 967 & 46 & -24.5 & 21.3 \\
\hline & $60-70$ & 4 & 82 & 14 & 1.0 & 753 & 33 & -24.5 & 19.2 \\
\hline & mean & $5(1)$ & $81(1)$ & $13(0)$ & $1.1(0)$ & $11712^{*}$ & $34(3)$ & $-24.4(0.2)$ & $19.5(1.8)$ \\
\hline \multirow[t]{13}{*}{$\mathrm{C} 24$} & $0-5$ & 16 & 72 & 12 & 1.4 & 1093 & 60 & -25.1 & 17.1 \\
\hline & $5-10$ & 16 & 73 & 11 & 1.6 & 1295 & 63 & -25.0 & 19.6 \\
\hline & $15-20$ & 7 & 80 & 13 & 1.5 & 1523 & 48 & -25.3 & 16.1 \\
\hline & $20-25$ & 8 & 80 & 12 & 1.4 & 1091 & 49 & -25.0 & 15.4 \\
\hline & $25-30$ & 9 & 79 & 12 & 2.1 & 1495 & 63 & -25.3 & 20.8 \\
\hline & $35-38$ & 10 & 78 & 12 & 1.5 & 346 & 56 & -25.1 & 17.9 \\
\hline & $38-43$ & 17 & 73 & 10 & 1.7 & 1360 & 58 & -25.2 & 18.8 \\
\hline & $43-48$ & 14 & 75 & 11 & 1.6 & 1164 & 55 & -25.2 & 19.3 \\
\hline & $48-53$ & 9 & 79 & 12 & 1.3 & 1051 & 41 & -25.1 & 16.3 \\
\hline & $58-63$ & 10 & 81 & 9 & 1.2 & 1013 & 37 & -24.8 & 14.7 \\
\hline & $68-73$ & 7 & 81 & 12 & 1.0 & 877 & 29 & -24.9 & 12.9 \\
\hline & $75-80$ & - & & - & 0.7 & 809 & 42 & -24.9 & 18.2 \\
\hline & mean & 11(1) & $77(1)$ & $12(0)$ & $1.4(0.1)$ & $13118^{*}$ & $50(3)$ & $-25.1(0.2)$ & 17.3 \\
\hline
\end{tabular}

${ }^{*}$ Total value for the whole profile 
Table 4. Mean Enrichment Ratio (ER) and associated Standard Error (SE) for A and B profiles (taking topsoil 0-10 cm as reference soil values).

\begin{tabular}{|c|c|c|c|c|c|c|c|c|c|c|c|c|c|}
\hline & & & & A & & & & & & B & & & \\
\hline \multirow{3}{*}{ C51 } & & Sand & Silt & Clay & $\mathrm{OC}$ & POC & MOC & Sand & Silt & Clay & OC & POC & MOC \\
\hline & ER & $0.18^{\mathrm{b} *}$ & 1.37 & 1.12 & $0.48^{a *}$ & 0.40 & $0.84^{\mathrm{a} *}$ & $1.58^{\mathrm{a} *}$ & $0.59^{b}$ & $0.50^{\mathrm{b}}$ & $0.34^{*}$ & $0.47^{\mathrm{a}}$ & $0.39^{*}$ \\
\hline & SE & 0.03 & 0.01 & 0.02 & 0.02 & 0.04 & 0.08 & 0.05 & 0.04 & 0.05 & 0.02 & 0.03 & 0.03 \\
\hline \multirow[t]{2}{*}{ C24 } & ER & $0.36^{\mathrm{a}}$ & 1.33 & 1.09 & $0.40^{\mathrm{b} *}$ & $0.32^{*}$ & $0.45^{\mathrm{b} *}$ & $0.52^{\mathrm{b}}$ & $1.26^{\mathrm{a}}$ & $1.00^{\mathrm{a}}$ & $0.28^{*}$ & $0.18^{\mathrm{b} *}$ & $0.31^{*}$ \\
\hline & SE & 0.04 & 0.02 & 0.03 & 0.04 & 0.02 & 0.02 & 0.02 & 0.00 & 0.02 & 0.03 & 0.03 & 0.03 \\
\hline
\end{tabular}

ab: significant differences within A sediment profiles in C51 and C24 (per columns) $(p<0.05)$; ${ }^{*}$ significant differences between profiles A and B in each wedge ( $\left.p<0.05\right)$.

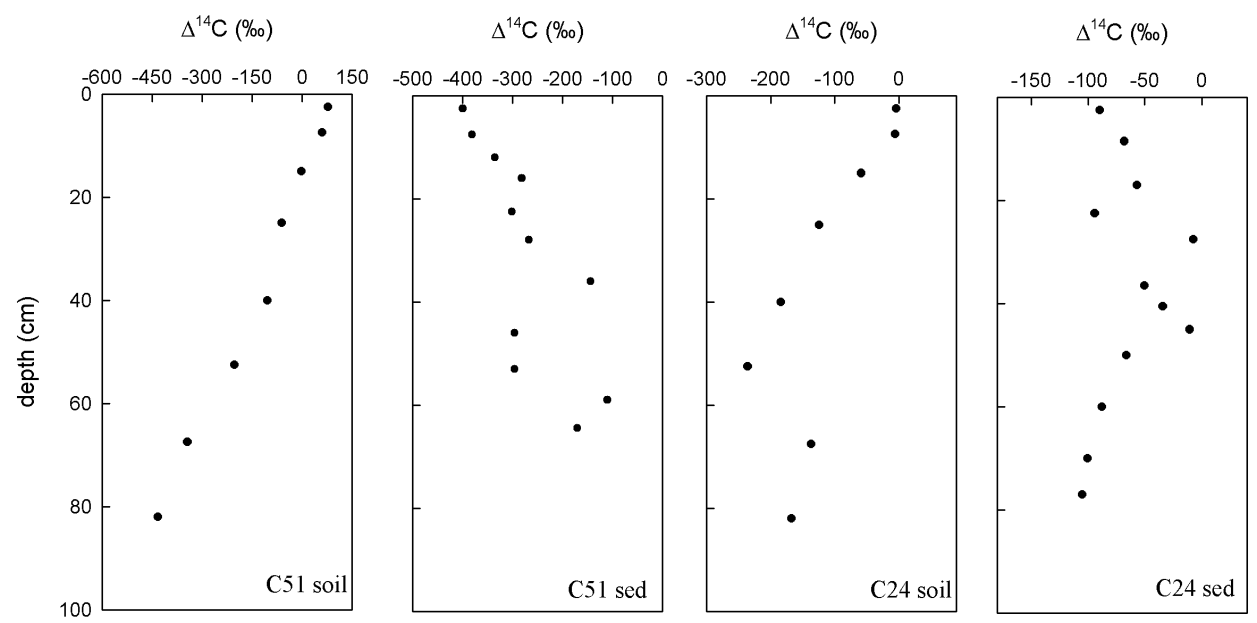

Fig. 4. $\Delta^{14} \mathrm{C}(\%)$ values at the different depths in the soil (soil) and sediment profiles (sed).

in C24 sediment samples with an OC concentration similar to that of other soil samples had more negative $\delta^{13} \mathrm{C}$ and less negative $\Delta^{14} \mathrm{C}$ values (Fig. 5).

The C:N ratio decreased in depth in the soil profiles of C51 and $\mathrm{C} 24$ ranging between 21.4 (topsoil) and 9.8 (deep soil) in C51, while in C24 the ratio ranged between and 24.4 (topsoil) and 17.1 (deep soil). The sediments at the depositional site in $\mathrm{C} 51$ showed a mean $\mathrm{C}: \mathrm{N}$ ratio that was significantly higher $(p<0.05)$ than that of soils, whereas in $\mathrm{C} 24$ no differences were found between both.

Table 5 shows correlation coefficients for the analysed profiles between carbon isotopes and OC, POC, C:N and clay content. We observed a significant negative correlation $(p<0.05)$ of $\delta^{13} \mathrm{C}$ with $\Delta^{14} \mathrm{C}$, OC and POC and a positive correlation with clay content though only significant $(p<0.05)$ in soil samples. Further, by taking all sediment samples together, an adjusted $R^{2}$ of $0.48(p<0.01)$ was found between $\delta^{13} \mathrm{C}$ and $\mathrm{C}: \mathrm{N}$ values, but it was not significant for soil samples.

\subsection{OC input, outputs and burial efficiency}

The OC input $\left(\mathrm{C}_{\mathrm{in}}\right)$ obtained by our calculations was similar for the slopes of both subcatchments (C51: $22 \mathrm{~g} \mathrm{~m}^{-2} \mathrm{yr}^{-1}$ and $\mathrm{C} 24$ : $24 \mathrm{~g} \mathrm{~m}^{-2} \mathrm{yr}^{-1}$ ) and always higher than the estimated erosion rates, whether these came from the WATEM/SEDEM model $\left(<1 \mathrm{~g} \mathrm{~m}^{-2} \mathrm{yr}^{-1}\right)$ or field-estimated sediment yield (1.9 and $5.6 \mathrm{~g} \mathrm{~m}^{-2} \mathrm{yr}^{-1}$, for $\mathrm{C} 51$ and $\mathrm{C} 24$, respectively) (Boix-Fayos et al., 2008). The first-order loss constants $(k)$ obtained with the model were $1.43 \times 10^{-3}$ and $0.96 \times 10^{-3} \mathrm{yr}^{-1}$ for C51 and C24, of which the erosion component represented 8 and $22 \%$, of the field estimated erosion rates for $\mathrm{C} 51$ and $\mathrm{C} 24$, respectively.

The OC inventory was higher in soils than in sediments in C51 and C24 (Fig. 6) due to the higher OC concentration in soil profiles. Burial efficiency, that depends also on $\Delta^{14} \mathrm{C}$ values, was greater in sediments in C51 (lower $\mathrm{FM}_{w}$ value) while in $\mathrm{C} 24$ it was greater for the soil than the sediment profile. 

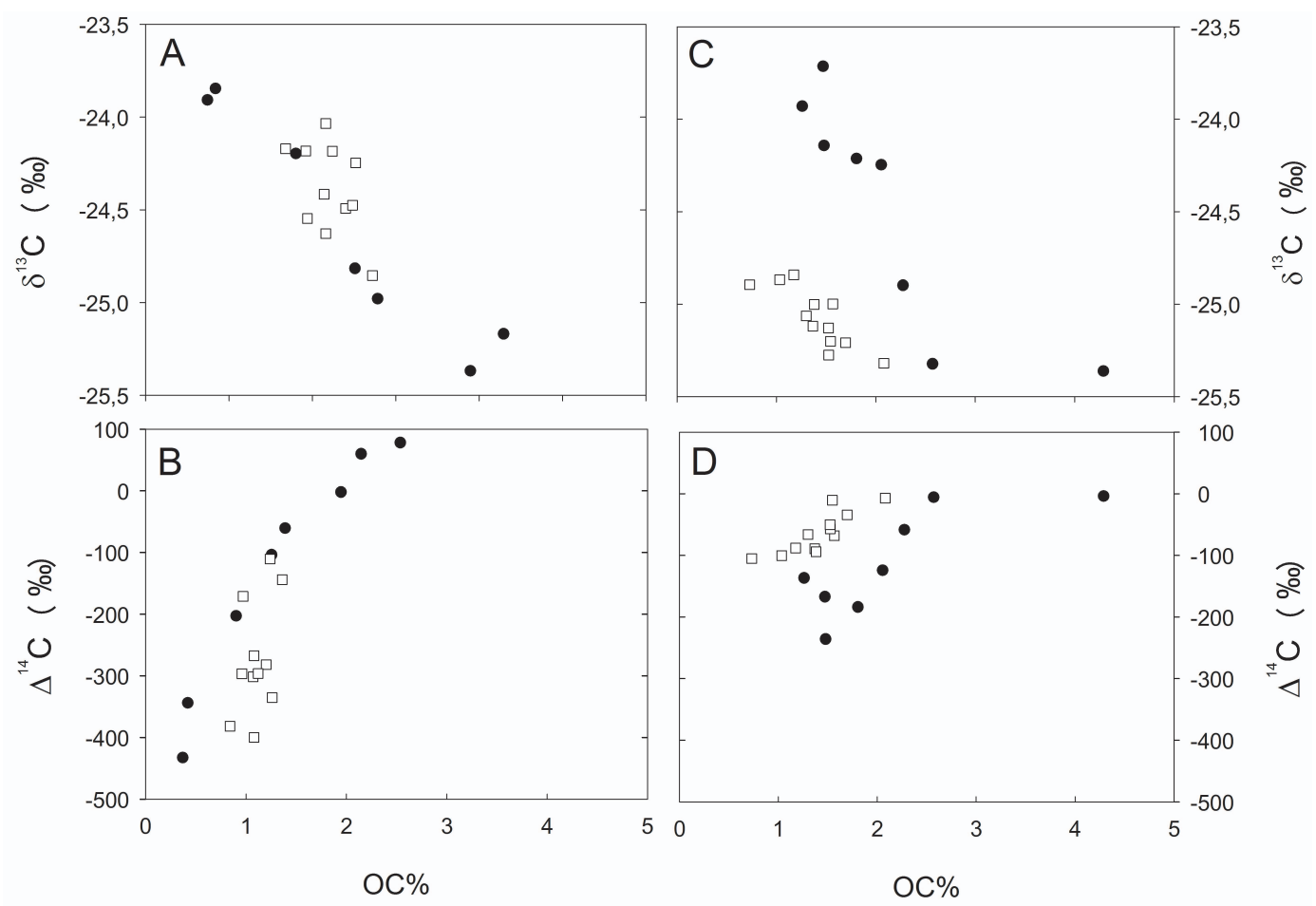

Fig. 5. $\Delta^{14} \mathrm{C}, \delta^{13} \mathrm{C}$, and $\mathrm{OC} \%$ in $\mathrm{C} 51(\mathbf{A}$ and $\mathbf{B})$ and $\mathrm{C} 24(\mathbf{C}$ and $\mathbf{D})$. Black dots represent soil samples and white squares sediment samples.

Table 5. Correlation coefficients between $\delta^{13} \mathrm{C}, \Delta^{14} \mathrm{C}$ and selected variables (Spearman's rho reported) ${ }^{*} p<0.05,{ }^{* *} p<0.01$

\begin{tabular}{lrrrrrr}
\hline & $\delta^{13} \mathrm{C}(\%)$ & OC $(\%)$ & POC $(\%)$ & MOC $(\%)$ & C:N ratio & Clay $(\%)$ \\
\hline Soil 51 & & & & & & \\
$\Delta^{14} \mathrm{C}$ & $-0.932^{* *}$ & $0.964^{* *}$ & $0.872^{* *}$ & $0.969^{* *}$ & 0.524 & $-0.971^{* *}$ \\
$\delta^{13} \mathrm{C}$ & & $-0.973^{* *}$ & $-0.925^{* *}$ & $-0.954^{* *}$ & -0.371 & $0.977^{* *}$ \\
Sediment 51 & & & & & & \\
$\Delta^{14} \mathrm{C}$ & $-0.789^{* *}$ & 0.471 & $0.824^{* *}$ & $-0.736^{*}$ & 0.631 & -0.356 \\
$\delta^{13} \mathrm{C}$ & & -0.499 & $-0.748^{* *}$ & 0.563 & -0.381 & 0.129 \\
Soil 24 & & & & & & \\
$\Delta^{14} \mathrm{C}$ & $-0.878^{* *}$ & $0.784^{* *}$ & $0.801^{*}$ & $0.750^{*}$ & -0.219 & -0.687 \\
$\delta^{13} \mathrm{C}$ & & $-0.860^{* *}$ & $-0.895^{* *}$ & $-0.818^{*}$ & 0.467 & $0.780^{*}$ \\
Sediment 24 & & & & & & \\
$\Delta^{14} \mathrm{C}$ & $-0.797^{* *}$ & $0.837^{* *}$ & $0.758^{* *}$ & 0.253 & $0.702^{*}$ & 0.178 \\
$\delta^{13} \mathrm{C}$ & & $-0.784^{* *}$ & $-0.733^{*}$ & -0.218 & -0.557 & -0.530 \\
\hline
\end{tabular}

\section{Discussion}

\subsection{Identification of $\mathrm{OC}$ sources}

The geomorphological survey, OC concentrations, OC distribution among fractions (POC versus MOC) and the isotope signatures suggested that $\mathrm{C} 51$ and $\mathrm{C} 24$ had diverging erosion dynamics and sediment sources at the time of the study due to different geomorphological processes in the channel and the slope-streambed connections. Autochthonous input of OC at the depositional settings was not quantified but it was assumed to be of equal importance for the profiles in both subcatchments (same vegetation close to the sampled locations) and of little significance for the total OC stock compared to soil OC input by lateral redistribution. 


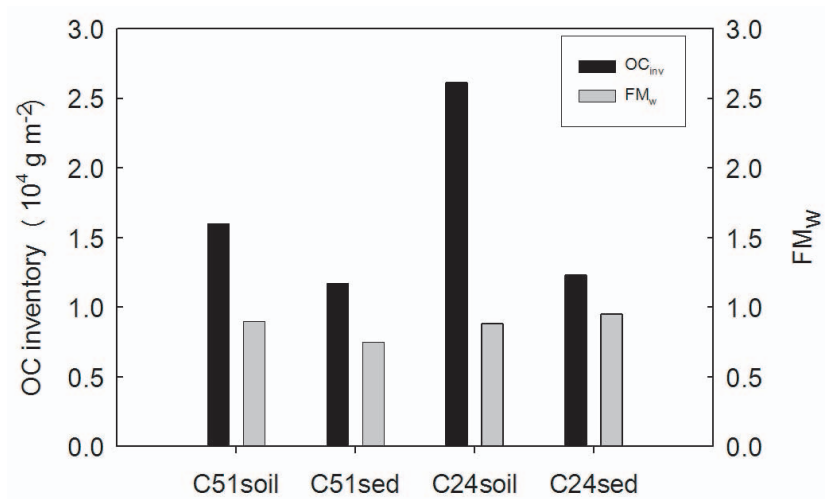

Fig. 6. Organic carbon inventory and $\mathrm{FM}_{w}$ (see Sect. 2.6) at the eroding (soil) and depositional sites (sed).

\subsubsection{Old OC sources}

In C51, sediments reaching the check-dam were mainly derived from deep soil through processes such as mass wasting, bank erosion, gullies and bed erosion. The occurrence of erosion processes that transport deep soil in C51 was related to land use change and lithology, both of which can greatly influence the characteristics of the mobilized OC in catchments (Longworth et al., 2007). Lithology, a key component in sediment delivery (de Vente et al., 2011; Haregeweyn et al., 2006) was sensitive to the formation of gullies and mass movements in the slope-streambed connection of C51. On the other hand, the land use change analysis indicated a conversion of dry-land agriculture to forest through reforestation from 1956 to 1981, and an increase in forest cover density from 1981 to 2008 . Those changes suggest that rill and interrill erosion of topsoil are likely to have decreased due to the disappearance of dry-land agricultural areas and the recovery of vegetation in former agricultural land. These shifts may have led to a decreased input of sediments from the slopes to the river channel causing a sediment deficit in fluvial transport while activating other erosion processes such as river bed erosion and bank erosion, as seen in the morphological cartography and in agreement with other areas of the Rogativa (Boix-Fayos et al., 2007). This change in sediment sources, and sediment availability, is consistent with the $\Delta^{14} \mathrm{C}$ signature in the A sediment profile of C51. In this profile, less negative $\Delta^{14} \mathrm{C}$ values were found at the bottom of the profile and gradually shifted towards more negative $\Delta^{14} \mathrm{C}$ values close to the surface. These sediments presented OC characteristics $\left(\Delta^{14} \mathrm{C}, \delta^{13} \mathrm{C}\right)$ that matched those of deeper soil layers (i.e. $>30 \mathrm{~cm}$ ) of the drainage area in the subcatchment, an observation that is in agreement with other studies that report transport of old OC in rivers when the dominant erosion processes deliver material from deeper soil layers and bedrock in the source areas into river channels (Gómez et al., 2010; Longworth et al., 2007; Masiello and Druffel, 2001).

\subsubsection{Young OC sources}

The slopes of $\mathrm{C} 24$ were well connected to the stream delivering topsoil OC through interrill and rill erosion processes, causing aggradation of the channel. This subcatchment was characterised by few changes in shrubland and forest over the previous 50 years and by a very small presence of agricultural land, and, given the absence of any climatic trends, it is also unlikely to have experienced a shift in the dominant erosion processes during this time period. The very small changes in $\Delta^{14} \mathrm{C}, \mathrm{g} \delta{ }^{13} \mathrm{C}$ and $\mathrm{OC}$ values with depth in the A sediment profile also point towards the input of sediments with uniform characteristics. This input was also influenced by the outcrop of quaternary glacis that resulted in a high input of coarse particles and rocks (debris) that were incorporated into the channel by rill erosion and gravity and led to channel aggradation. Evidence for the mobilization of topsoil material in the sediment wedge also came from the matching of the sediment $\Delta^{14} \mathrm{C}, \delta^{13} \mathrm{C}$ and $\mathrm{OC}$ values with those in the top $20 \mathrm{~cm}$ of the sampled soil profiles in the eroding subcatchment and the fact that in this subcatchment the POC fraction represented $50 \%$ of total OC (while in C51 it was only $34 \%$ ), and the POC fraction was higher in the upper soil horizons (Table 2).

\subsection{Mineralization, selective deposition, and preservation of buried $\mathrm{OC}$}

The OC enrichment ratios observed in the sediment profiles in our subcatchments were low compared to those observed in sediments of other drainage areas of similar size (Avnimelech and McHenry, 1984; Chaplot et al., 2005; Fiener et al., 2005; Jacinthe et al., 2004). Low OC enrichment ratios at transitory depositional sites can indicate that selective deposition of coarse mineral particles with low OC content is taking place while fine mineral particles rich in OC are exported with runoff (Fiener et al., 2005; Starr et al., 2000; Wang et al., 2010) or that OC is being mineralized before or after deposition (Gregorich et al., 1998). At our depositional sites, the use of $\mathrm{OC}$ and particle-size enrichment ratios, $\delta^{13} \mathrm{C}$ and $\mathrm{C}: \mathrm{N}$ ratios as indicators of mineralization (Wang et al., 2010) did not clarify the role of mineralization processes on OC loss at depositional sites.

\subsubsection{Particle-size selectivity and OC export}

At the depositional sites, selective deposition of soil particles, pebbles and rocks was observed. Based on Stocke's law, coarser particles settle before finer ones (Gee and Bauder, 1986) and because finer particles are associated with higher OC contents, it can be expected that sediment exported beyond depositional sites will often be C-enriched, while sediment remaining at these sites can become C-depleted (Wang et al., 2010). In our case, a slightly higher proportion of fine particles was found in sediments, compared to 
the soils in the drainage area, but they were not associated with an increase in OC concentration. Selective deposition was best observed when comparing the two sediment profiles (A and B) in each wedge. In C51, an enrichment in finer particles was observed in the wedge front (A) whereas, an enrichment in coarser particles indicating a gradual deposition within the sediment wedge was observed in the back (B). Preferential deposition of coarser particles at the back of the sediment wedge was not observed in C24. Suspended sediment may have been an important source of material in the depositional site of $\mathrm{C} 24$ while bedload, carrying coarser particles, was relatively more important in C51. In both cases, an unknown percentage of the $\mathrm{OC}$ in runoff may have been exported downstream of the check-dam, but the percentage of fine particles in the sediment wedge, similar to that in the sampled subcatchment's soils, showed no evidence of a strong particle-size selectivity on export.

\subsubsection{Fate of buried $\mathrm{OC}$}

OC mineralization is always considered an important factor affecting sediment OC content although it has very seldom been assessed at a field scale due to the influence exerted by several factors (moisture, porosity, temperature) that interact in a complex way (Van Hemelryck et al., 2010, 2011). By using an indirect approach (as in Wang et al., 2010) we discuss the importance of mineralization at our study sites based on $\mathrm{C}: \mathrm{N}$ ratios, OC and clay enrichment ratios and $\delta^{13} \mathrm{C}$ values. Considering that the $\mathrm{C}: \mathrm{N}$ ratio tends to decrease when mineralization takes place (Conen et al., 2008), the lower or equal C:N values found in soil samples compared to sediment samples in both subcatchments, indicated non important mineralization processes in sediments. Similarly, $\delta^{13} \mathrm{C}$ values tend to become less negative as $\mathrm{OC}$ decomposes but no differences were observed between soil and sediment $\delta^{13} \mathrm{C}$ values in both subcatchments. Therefore, we found no evidences of significant mineralization by using C:N and $\delta^{13} \mathrm{C}$ despite the difference observed between clay and $\mathrm{OC}$ enrichment ratios that could lead to an opposed conclusion.

Finally, further studies on the effect of erosion on OC dynamics could benefit from consideration of stability and stabilization mechanisms of eroded OC after it is deposited downslope or downstream that constrain OC decomposition. In our study, reduced accessibility to OC through burial appears to have served as an effective mechanism of OC stabilization in the sediment profiles. The effect of this mechanism was enhanced in C51 by the contribution of old OC from channel incision leading to a higher $\mathrm{FM}_{w}$ at the depositional profile than that found in $\mathrm{C} 24$.

\subsection{OC replacement in eroded slopes}

Dynamic replacement of eroded OC in soil profiles, one component of the criterion for erosion to constitute a carbon sink (Berhe et al., 2007; Harden et al., 1999; Stallard, 1998), was met in the soil profiles of C51 and C24. Mean plant derived-OC input (e.g. leaf-litter and fine root detritus) was higher than currently eroded soil OC suggesting that dynamic OC replacement was taking place in the studied soil profiles. In fact, the estimated current erosion rates represented less than $0.5 \%$ of the soil OC stock in the upper 5 $\mathrm{cm}$. The effective replacement rates indicated as well that the soil profiles were not in equilibrium and, thus, that erosion rates might have been higher in the past. These results are in accordance with Berhe et al. (2008) that reported effective replacement of $\mathrm{OC}$ transported from upland eroding landform positions using the same carbon isotope approach, and with other studies at different spatial scales (Liu et al., 2003; Quine and van Oost, 2007; Smith et al., 2005) indicating that the first part of the criterion for erosion to constitute a sink can be met in a variety of ecosystems.

Unanswered questions remain as to whether the rate of replacement of eroded OC is equally distributed in different OC pools, or if, as Van Oost et al. (2007) suggest, it can only be effective for certain carbon pools (those more active) reducing the capacity of the sink and its temporal significance.

\section{Conclusions}

Our findings underline the importance of tracing sediment sources when studying the redistribution and fate of soil OC by water erosion. In the studied subcatchments two different scenarios are likely to have taken place: (i) a dominance of selective erosion processes (interrill and rill erosion) in a subcatchment with a relatively dense and stable vegetation cover, that delivered material to the streambed and transported it in suspension before being deposited behind a check-dam, and (ii) processes of concentrated erosion (mass waste, gullies, channel erosion) in a subcatchment where reforestation of agricultural land and greening up took place over the past 50 years, leading as well to channel incision. These differences in the type of erosion processes were confirmed by a geomorphological survey of the slope-streambed connections. The use of carbon isotopes $\left({ }^{14} \mathrm{C}\right.$ and $\left.{ }^{13} \mathrm{C}\right)$ as tracers exemplified how differences in the sources of sediment may lead to very different sediment OC characteristics in depositional sites, with important implications for OC preservation. A profileintegrated carbon input in combination with current erosion rates showed that dynamic replacement was taking place in the two analysed soil profiles. Assessments of the overall carbon budget at the catchment scale should consider which sources are responsible for the main part of sediments and how these may vary over time due to land use changes. 
Acknowledgements. This work was financially supported by the following projects: ERCO (CGL-2007-62590/BTE) of the Spanish Ministry of Science and Innovation, ESUMA (11859/PI/09) of the Séneca Foundation of the Regional Government of Murcia and MIRAGE (FP7-ENV-2007-1). E. Nadeu received funding from a predoctoral fellowship of the Spanish Ministry of Science and Innovation (BES-2008-002379). A. A. Berhe acknowledges financial support from the University of California. We wish to especially thank Xiaomei Xu and Claudia Czimczik at UC Irvine for their valuable help in the isotope measurements; Loli Ruiz and Jorge López for their contribution in the field and laboratory work and Juan Manuel Quiñonero for GIS support. Special thanks also go to Steve Bouillon and two anonymous reviewers for enhancing the manuscript with their comments.

Edited by: S. Bouillon

\section{References}

Alewell, C., Meusburger, K., Brodbeck, M., and Bänninger, D.: Methods to describe and predict soil erosion in mountain regions, Landscape Urban Plan., 88, 46-53, 2008.

Alin, S. R., Aalto, R., Goni, M. A., Richey, J. E., and Dietrich, W. E.: Biogeochemical characterization of carbon sources in the Strickland and Fly rivers, Papua New Guinea, J. Geophys. ResEarth., 113, F01S05, doi:10.1029/2006jf000625, 2008.

Avnimelech, Y. and McHenry, J. R.: Enrichment of transported sediments with organic carbon, nutrients and clay, Soil Sci. Soc. Am. J., 48, 259-266, 1984.

Berhe, A. A.: Decomposition of organic substrates at eroding vs. depositional landform positions, Plant Soil, 350, 261-280, 2012.

Berhe, A. A., Harte, J., Harden, J. W., and Torn, M. S.: The significance of the erosion-induced terrestrial carbon sink, BioScience, 57, 337-346, 2007.

Berhe, A. A., Harden, J. W., Torn, M. S., and Harte, J.: Linking soil organic matter dynamics and erosion-induced terrestrial carbon sequestration at different landform positions, J. Geophys. ResBiogeo., 113, 2008.

Berhe, A. A., Harden, J. W., Torn, M. S., Kleber, M., Burton, S. D., and Harte, J.: Stabilization of soil organic matter in eroding and depositional landform positions, J. Geophys. Res.-Biogeo., accepted, 2012.

Boix-Fayos, C., Barberá, G. G., López-Bermúdez, F., and Castillo, V. M.: Effects of check dams, reforestation and land-use changes on river channel morphology: Case study of the Rogativa catchment (Murcia, Spain), Geomorphology, 91, 103-123, 2007.

Boix-Fayos, C., de Vente, J., Martinez-Mena, M., Barbera, G. G., and Castillo, V.: The impact of land use change and check-dams on catchment sediment yield, Hydrol. Process., 22, 4922-4935, 2008.

Bronk Ramsey, C.: Bayesian analysis of radiocarbon dates, 1, University of Arizona, Tucson, AZ, United States, 24 pp., 2009.

Chaplot, V. A. M., Rumpel, C., and Valentin, C.: Water erosion impact on soil and carbon redistributions within uplands of Mekong River, Global Biogeochem. Cy., 19, GB4004, doi:10.1029/2005GB002493, 2005.
Collins, A. L., Walling, D. E., and Leeks, G. J. L.: Source type ascription for fluvial suspended sediment based on a quantitative composite fingerprinting technique, Catena, 29, 1-27, 1997.

Conen, F., Zimmermann, M., Leifeld, J., Seth, B., and Alewell, C.: Relative stability of soil carbon revealed by shifts in $\delta^{15} \mathrm{~N}$ and C:N ratio, Biogeosciences, 5, 123-128, doi:10.5194/bg-5-1232008, 2008.

de Vente, J., Verduyn, R., Verstraeten, G., Vanmaercke, M., and Poesen, J.: Factors controlling sediment yield at the catchment scale in NW Mediterranean geoecosystems, J. Soil. Sediment., 11, 690-707, 2011.

Fiener, P., Auerswald, K., and Weigand, S.: Managing erosion and water quality in agricultural watersheds by small detention ponds, Agr. Ecosyst. Environ., 110, 132-142, 2005.

Gaudinski, J. B., Trumbore, S. E., Davidson, E. A., and Zheng, S.: Soil carbon cycling in a temperate forest: Radiocarbon-based estimates of residence times, sequestration rates and partitioning of fluxes, Biogeochemistry, 51, 33-69, 2000.

Gee, G. W. and Bauder, J. W.: Particle-size Analysis, in: Methods of soil analysis, Part 1, Physical and Mineralogical Methods $\left(2^{\text {nd }}\right.$ edition), edited by: Klute, A., Soil Sci. Soc. Am., Madison, Wis., 393-394, 1986.

Gómez, B., Baisden, W. T., and Rogers, K. M.: Variable composition of particle-bound organic carbon in steepland river systems, J. Geophys. Res., 115, F04006, doi:10.1029/2010JF001713, 2010.

Gregorich, E. G., Greer, K. J., Anderson, D. W., and Liang, B. C.: Carbon distribution and losses: Erosion and deposition effects, Soil Till. Res., 47, 291-302, 1998.

Haregeweyn, N., Poesen, J., Nyssen, J., De Wit, J., Haile, M., Govers, G., and Deckers, S.: Reservoirs in Tigray (Northern Ethiopia): Characteristics and sediment deposition problems, Land Degrad. Dev., 17, 211-230, 2006.

Harden, J. W., Sharpe, J. M., Parton, W. J., Ojima, D. S., Fries, T. L., Huntington, T. G., and Dabney, S. M.: Dynamic replacement and loss of soil carbon on eroding cropland, Global Biogeochem. Cy., 13, 885-901, 1999.

Harrison, K. G., Broecker, W. S., and Bonani, G.: The effect of changing land use on soil radiocarbon, Science, 262, 725-726, 1993.

Hilton, R.G., Galy, A., and Hovius, N.: Riverine particulate organic carbon from an active moutain belt: Importance of landslides, Global Biogeochem. Cy., 22, BG1017, doi:10.1029/2006GB002905, 2008.

Hooke, J.: Coarse sediment connectivity in river channel systems: a conceptual framework and methodology, Geomorphology, 56, 79-94, 2003.

Instituto Geológico y Minero de España (IGME): Mapa geológico de España 1:50000, Nerpio 909, 23-26, 1978.

Jacinthe, P. A., Lal, R., Owens, L. B., and Hothem, D. L.: Transport of labile carbon in runoff as affected by land use and rainfall characteristics, Soil Till. Res., 77, 111-123, 2004.

Katsuno, K., Miyairi, Y., Tamura, K., Matsuzaki, H., and Fukuda, $\mathrm{K}$.: A study of the carbon dynamics of Japanese grassland and forest using ${ }^{14} \mathrm{C}$ and ${ }^{13} \mathrm{C}$, Nucl. Instrum. Meth. B, 268, 1106$1109,2010$.

Kitagawa, H., Lim, J., Takemura, K., Hayashida, A., and Haraguchi, T.: Radiocarbon content of lignin-enriched fraction in core sediment from Lake Biwa, central Japan, Nucl. Instrum. 
Meth. B, 268, 1077-1079, 2010.

Lambert, T., Pierson-Wickmann, A.-C., Gruau, G., Thibault, J.-N., and Jaffrezic, A.: Carbon isotopes as tracers of dissolved organic carbon sources and water pathways in headwater catchments, J. Hydrol., 402, 228-238, 2011.

Liu, S. G., Bliss, N., Sundquist, E., and Huntington, T. G.: Modeling carbon dynamics in vegetation and soil under the impact of soil erosion and deposition, Global Biogeochem. Cy., 17, 1074, doi:10.1029/2002GB002010, 2003.

Longworth, B. E., Petsch, S. T., Raymond, P. A., and Bauer, J. E.: Linking lithology and land use to sources of dissolved and particulate organic matter in headwaters of a temperate, passivemargin river system, Geochim. Cosmochim. Ac., 71, 4233-4250, 2007.

Marzaioli, F., Lubritto, C., Galdo, I. D., D’Onofrio, A., Cotrufo, M. F., and Terrasi, F.: Comparison of different soil organic matter fractionation methodologies: Evidences from ultrasensitive ${ }^{14} \mathrm{C}$ measurements, Nucl. Instrum. Meth. B, 268, 1062-1066, 2010.

Masiello, C. A. and Druffel, E. R. M.: Carbon isotope geochemistry of the Santa Clara River, Global Biogeochem. Cy., 15, 407-416, 2001.

Masiello, C. A., Chadwick, O. A., Southon, J., Torn, M. S., and Harden, J. W.: Weathering controls on mechanisms of carbon storage in grassland soils, Global Biogeochem. Cy., 18, 1-9, 2004.

McCallister, S. L., Bauer, J. E., Cherrier, J. E., and Ducklow, H. W.: Assessing sources and ages of organic matter supporting river and estuarine bacterial production: A multiple-isotope $\left(\Delta^{14} \mathrm{C}\right.$, $\delta^{13} \mathrm{C}$, and $\left.\delta^{15} \mathrm{~N}\right)$ approach, Limnol. Oceanogr., 49, 1687-1702, 2004.

Nadeu, E., de Vente, J., Martínez-Mena, M., and Boix-Fayos, C.: Exploring particle size distribution and organic carbon pools mobilized by different erosion processes at the catchment scale, J. Soil. Sediment., 11, 667-678, 2011.

Quine, T. A. and van Oost, K.: Quantifying carbon sequestration as a result of soil erosion and deposition: Retrospective assessment using caesium-137 and carbon inventories, Global Change Biol., 13, 2610-2625, 2007.

Raymond, P. A. and Bauer, J. E.: Use of ${ }^{14} \mathrm{C}$ and ${ }^{13} \mathrm{C}$ natural abundances for evaluating riverine, estuarine, and coastal DOC and POC sources and cycling: a review and synthesis, Org. Geochem., 32, 469-485, 2001.

Romero-Diaz, A., Alonso-Sarria, F., and Martinez-Lloris, M.: Erosion rates obtained from check-dam sedimentation (SE Spain), A multi-method comparison, Catena, 71, 172-178, 2007.

Saint-Laurent, D., Lavoie, L., Drouin, A., St-Laurent, J., and Ghaleb, B.: Floodplain sedimentation rates, soil properties and recent flood history in southern Québec, Global Planet. Change, 70, 76-91, 2010.

Schiff, S. L., Aravena, R., Trumbore, S. E., Hinton, M. J., Elgood, R., and Dillon, P. J.: Export of DOC from forested catchments on the Precambrian Shield of central Ontario: Clues from ${ }^{13} \mathrm{C}$ and ${ }^{14} \mathrm{C}$, Biogeochemistry, 36, 43-65, 1997.
Smith, S. V., Sleezer, R. O., Renwick, W. H. and Buddemeier, R.: Fates of eroded soil organic carbon: Mississippi basin case study. Ecol. Appl., 15, 1929-1940, 2005.

Southon, J., and Santos GM.: Life with MC-SNICS. Part II: recent ion source development at the Keck Carbon Cycle AMS Facility, Nucl. Instrum. Meth. B, 259, 88-93, 2007.

Stallard, R. F.: Terrestrial sedimentation and the carbon cycle: Coupling weathering and erosion to carbon burial, Global Biogeochem. Cy., 12, 231-257, 1998.

Starr, G. C., Lal, R., Malone, R., Hothem, D., Owens, L., and Kimble, J.: Modeling soil carbon transported by water erosion processes, Land Degrad, Dev., 11, 83-91, 2000.

Stuiver, M. and Polach, H. A.: Discussion reporting of ${ }^{14} \mathrm{C}$ data, Radiocarbon, 19, 355-363, 1977.

Torn, M. S., Lapenis, A. G., Timofeev, A., Fischer, M. L., Babikov, B. V., and Harden, J. W.: Organic carbon and carbon isotopes in modern and 100-year-old-soil archives of the Russian steppe, Global Change Biol., 8, 941-953, 2002.

Trumbore, S. E. and Harden, J. W.: Accumulation and turnover of carbon in organic and mineral soils of the BOREAS northern study area, J. Geophys. Res.-Atmos., 102, 28817-28830, 1997.

Van Hemelryck, H., Fiener, P., Van Oost, K., Govers, G., and Merckx, R.: The effect of soil redistribution on soil organic carbon: an experimental study, Biogeosciences, 7, 3971-3986, doi:10.5194/bg-7-3971-2010, 2010.

Van Hemelryck, H., Govers, G., van Oost, K., and Merckx, R.: Evaluating the impact of soil redistribution on the in situ mineralization of soil organic carbon, Earth Surf. Proc. Land., 36, 427-438, 2011.

Van Oost, K., Quine, T. A., Govers, G., De Gryze, S., Six, J., Harden, J. W., Ritchie, J. C., McCarty, G. W., Heckrath, G., Kosmas, C., Giraldez, J. V., da Silva, J. R. M., and Merckx, R.: The impact of agricultural soil erosion on the global carbon cycle, Science, 318, 626-629, 2007.

Wang, Z., Govers, G., Steegen, A., Clymans, W., Van den Putte, A., Langhans, C., Merckx, R., and Van Oost, K.: Catchmentscale carbon redistribution and delivery by water erosion in an intensively cultivated area, Geomorphology, 124, 65-74, 2010.

Wei, X., Yi, W., Shen, C., Yechieli, Y., Li, N., Ding, P., Wang, N., and Liu, K.: ${ }^{14} \mathrm{C}$ as a tool for evaluating riverine POC sources and erosion of the Zhujiang (Pearl River) drainage basin, South China, Nucl. Instrum. Meth. B, 268, 1094-1097, 2010.

Xu, X., Trumbore, S. E., Zheng, S., Southon, J. R., McDuffee, K. E., Luttgen, M., and Liu, J. C.: Modifying a sealed tube zinc reduction method for preparation of AMS graphite targets: Reducing background and attaining high precision, Nucl. Instrum. Meth. B, 259, 320-329, 2007.

Yeomans, J. C., and Bremner, J. M.: A rapid and precise method for routine determination of organic carbon in soil, Comm. Soil Sci. Plan., 19, 1467-1476, 1988. 